\title{
BIOCLIMATIC MODELS OF THE DISTRIBUTIONS OF GYRFALCONS AND PTARMIGAN
}

\author{
Brian HuntLey ${ }^{1}$ and Rhys E. GReEN ${ }^{2,3}$ \\ ${ }^{1}$ School of Biological and Biomedical Sciences, Durham University, South Road, \\ Durham DH1 3LE, UK \\ ${ }^{2}$ Department of Zoology, University of Cambridge, Downing Street, Cambridge CB2 3EJ, UK. \\ E-mail: reg29@cam.ac.uk \\ ${ }^{3}$ Royal Society for the Protection of Birds, The Lodge, Sandy, Bedfordshire SG19 2DL, UK
}

\begin{abstract}
Climatic Response Surface (CRS) models were fitted to the recorded global breeding distributions during the late $20^{\text {th }}$ Century of Gyrfalcon (Falco rusticolus), Willow Ptarmigan (Lagopus lagopus), Rock Ptarmigan (Lagopus muta), and White-tailed Ptarmigan (Lagopus leucura). These models describe the geographical distribution of each species by estimating its probability of occurrence per map grid cell in a three-dimensional climatic space defined by the 1961-1990 mean values of three variables: (1) mean temperature of the coldest month; (2) annual sum of day-degrees above $5^{\circ} \mathrm{C}$; and (3) ratio of actual evapotranspiration to potential evapotranspiration. Simulated potential late $20^{\text {th }}$ Century distributions were then obtained by calculating expected probability of occurrence using 1961-1990 climate and simulating presence of the species in those grid cells for which the modelled probability of occurrence exceeded a threshold value selected so as to maximize a measure of goodness-of-fit, Cohen's $x$. The CRS models were then used to simulate expected potential distributions of each species for projected climates in the late $21^{\text {st }}$ Century and for selected past climates during the late Quaternary. Simulated distributions for 1961-1990 from CRS models matched observed distributions reasonably well for Gyrfalcon, Willow Ptarmigan and Rock Ptarmigan, but not for White-tailed Ptarmigan, for which the simulated distribution extended to areas of Europe and Asia far from the actual distribution in western North America. For this reason, White-tailed Ptarmigan was excluded from further analysis. The simulated potential ranges of Gyrfalcon, Willow Ptarmigan and Rock Ptarmigan were similar in extent and location in the last interglacial, the warmest period of the Holocene and the $20^{\text {th }}$ Century. The extent of the simulated ranges of these species was substantially reduced in North America and increased in Europe and Asia during the Last Glacial Maximum. Simulated potential range extent in the late $21^{\text {st }}$ Century was projected to be smaller for Gyrfalcon, Willow Ptarmigan and Rock Ptarmigan, compared with that in the last interglacial, the Last Glacial Maximum, the warmest period of the Holocene, and the $20^{\text {th }}$ Century. Received 22 April 2011, accepted 28 June 2011.
\end{abstract}

Huntley, B., AND R. E. GREen. 2011. Bioclimatic models of the distributions of Gyrfalcons and ptarmigan. Pages 329-338 in R. T. Watson, T. J. Cade, M. Fuller, G. Hunt, and E. Potapov (Eds.). 
Gyrfalcons and Ptarmigan in a Changing World, Volume II. The Peregrine Fund, Boise, Idaho, USA. http://dx.doi.org/ 10.4080/gpcw.2011.0312

Key words: Climatic Response Surface model, climate envelope, projected potential distribution, climatic change.

WE KNOW FROM THE QUATERNARY FOSSIL record that past distributions of species of many kinds, especially those currently associated with the Arctic and sub-Arctic, often have been substantially different from their present distributions. Past climatic change has been a major driver of these changes in distribution. In this paper we use a type of climate envelope model, the Climatic Response Surface (CRS), to describe the recent breeding distributions of Gyrfalcon (Falco rusticolus), Willow Ptarmigan (Lagopus lagopus), Rock Ptarmigan (Lagopus muta), and White-tailed Ptarmigan (Lagopus leucura). We then use the models to simulate past potential distributions during the late Quaternary and potential future distributions in the late $21^{\text {st }}$ Century under various projections of climatic change.

\section{MethodS}

We fitted CRS models to global distribution data derived from maps compiled by BirdLife International and held at the BirdLife International Secretariat at Cambridge, UK in ESRI shapefile format. The BirdLife International maps refer mainly to the distributions of species recorded in the late $20^{\text {th }}$ Century and are derived from various sources, for which documentation is supplied. Further details are available at http://www.birdlife.org/datazone/ info/spcdownload. We used only those parts of the BirdLife International maps that show distribution during the breeding season. To do this we combined areas mapped as occupied in the breeding season only with those mapped as occupied at all times of year. Distributions were converted to presence or absence within each cell of a $0 \cdot 5^{\circ}$ longitude $\times$ latitude grid extending from $30^{\circ} \mathrm{N}$ to $85^{\circ} \mathrm{N}$.
The climatic data that we have used are derived from the global compilation on a $0.5^{\circ}$ longitude $\times$ latitude grid made by New et al. (1999) for the 30-year interval 1961-90. The gridded data were generated using an interpolation with respect to altitude, as well as to longitude and latitude, using the technique developed by Hutchinson (1989). Values were obtained for monthly mean temperatures, mean monthly precipitation and monthly mean proportion of potential sunshine received ('cloudiness'). The bioclimatic variables used in our modelling (see below) were then calculated for each cell from these climatic data using the approach and software developed by Prentice et al. (1992) and previously applied and described by Huntley et al. (1995). We used the following three bioclimatic variables:

- Mean temperature of the coldest month (MTCO: ${ }^{\circ} \mathrm{C}$ ): A measure of winter cold.

- Annual temperature sum above $5^{\circ} \mathrm{C}$ (GDD5: ${ }^{\circ} \mathrm{C}$ days): A measure of the overall warmth of the growing season for many plant species.

- Annual ratio of actual to potential evapotranspiration (AET/PET): Also referred to as Priestley-Taylor's $\alpha$, this measure of available moisture is estimated using a bucket model (Cramer and Prentice 1988), inputs to which include latitude, used to calculate potential insolation, and soil water capacity, derived from a global $0.5^{\circ}$ gridded dataset developed by Prentice et al. (1992), as well as 'daily' temperature, precipitation and cloudiness values estimated from the monthly means of these variables. This measure represents the availability of water to plants and other terrestrial organisms. 
We related probability of occurrence of a species within a $0 \cdot 5^{\circ}$ longitude $\times$ latitude cell to the three bioclimatic variables by fitting CRS models (Bartlein et al. 1986, Huntley 1995, Huntley et al. 1995, Hill et al. 2003, Huntley et al. 2004, 2006) that describe the form of the relationship between the distribution of a species and a small number of bioclimatic variables. Response surfaces were fitted using locally-weighted regression (Cleveland and Devlin 1988), thus making no assumptions about the form of the relationship between a species' probability of occurrence in a grid cell and the bioclimatic variables. Fitting was undertaken using a moving window with dimensions of $5^{\circ} \mathrm{C}$ (MTCO), $625^{\circ} \mathrm{C}$ days (GDD5) and $0 \cdot 125$ (AET/PET). The surfaces were evaluated at regularly spaced points ('nodes') positioned at intervals of $1^{\circ} \mathrm{C}$ (MTCO), 125 degree days (GDD5) and 0.025 (AET/PET), with 71, 60, and 41 nodes respectively along each bioclimatic axis. Values at the nodes were the probability of the species breeding at that location in climatic space; these values were calculated as inverse distance-weighted means of the observed probabilities of occurrence in those grid cells falling within the fitting window around the node, presence in a grid cell equating to a probability of $1 \cdot 0$ and absence to $0 \cdot 0$. The distance weighting used Euclidean distance in the three-dimensional space of the standardised climate variables, whilst weights were calculated using the tricube function, thus strongly weighting data points closest to the node (Huntley et al. 1995).

Having fitted the CRS model for a species, it can then be used to evaluate the species' probability of occurrence in a given cell from the observed values of the three bioclimatic variables used to fit the model. The required probability is obtained by interpolating between the values at the nodes of the fitted surface that surround the target locality in bioclimatic space. As in the model fitting step, the nodes to be taken into account are those within a defined window around the target locality, and the probability value is interpolated using an inverse distance weighting, weights being cal- culated using the tricube function. This provides an estimate of the species' probability of occurrence under these particular bioclimatic conditions. To generate a map of simulated distribution, we used a threshold value of probability of occurrence: probabilities greater than this threshold being taken to predict presence and those less than the threshold to predict absence. We selected as the threshold probability value that which optimises goodness-of-fit statistic Cohen's $x$ (Cohen 1960). The method for doing this is described in detail in Huntley et al. (2007). Within the area where the species was simulated to be present because the simulated probability of occurrence exceeded the threshold value, we also divided the simulated probability of occurrence into three bins representing relatively high, low and intermediate probabilities and colour coded these on the maps of simulated distribution.

We evaluated the goodness-of-fit of the CRS models to the $20^{\text {th }}$ Century distribution data used to fit them by calculating the area under the curve (AUC) for a receiver operating characteristic (ROC) plot of sensitivity against (1 specificity) for all possible values of threshold probability (Metz 1978). For the purposes of constructing an ROC plot, sensitivity is defined as the proportion of true positives correctly predicted and specificity as the proportion of true negatives correctly predicted.

We used the same methods to those used to generate maps of simulated probability of occurrence and distribution under recently observed climatic conditions to produce equivalent maps under past and future climatic conditions, as obtained from General Circulation Model (GCM) simulations. Past climates for 120,21 , and $7 \mathrm{ka} \mathrm{BP}$ were modelled using the HadCM3 GCM; the procedures used are described by Singayarer and Valdes (2010). These three times were selected to represent conditions typical of the last interglacial period, the Last Glacial Maximum (LGM) and the warmest period of the Holocene respectively. We based our maps on simulated prob- 
ability of occurrence from past climate for all $0 \cdot 5^{\circ}$ longitude $\times$ latitude grid cells considered to be land at the specified time, except that, at the LGM, species were taken to be absent in cells then covered by ice sheets according to Ehlers and Gibbard (2008). We took the extent of ice sheets at $120 \mathrm{ka} \mathrm{BP}$ and $7 \mathrm{ka} \mathrm{BP}$ to be the same as that at present.

We generated maps of potential future breeding distribution of the species using GCM projections of future climate averaged over the period 2070-2099. We used simulations from three GCMs: HadGEM1, GFDL-CM2.1, and ECHAM/MPI-OM. For all three GCMs, we used the A1B greenhouse gas emissions scenario, that results in stabilization of global annual mean atmospheric carbon dioxide concentration at $700-800$ ppmv.

To assess changes in the extent of the potential breeding distribution of the species over time we summed the area within which the species was simulated as potentially breeding at a particular time and divided by the extent of its simulated potential breeding distribution in the late $20^{\text {th }}$ Century. We call this relative range extent.

\section{RESULTS}

Comparison of the observed breeding distributions from the BirdLife International maps with simulated potential distributions for 1961-1990 from the CRS models fitted to them showed reasonably good agreement for Gyrfalcon, Willow Ptarmigan and Rock Ptarmigan (Figure 1). For all three species there was a tendency for the simulated distribution to extend further south than the observed distribution. For example, the simulated distribution of Willow Ptarmigan included the European Alps and the Caucasus, where it does not breed. The performance of the CRS model in simulating the observed distribution was least good for White-tailed Ptarmigan. For this species, although its actual distribution in western North America was simulated quite well, the simulated distribution also extended to areas distant from the species' range; to Kamchatka, parts of the Tibetan Plateau, and Scandinavia. The AUC values from the ROC plots were high for all four species, being 0.968 for Gyrfalcon, Willow Ptarmigan, and Rock Ptarmigan, and 0.942 for White-tailed Ptarmigan, indicating a good fit of the models to the data. However, it is the simulation of range for the White-tailed Ptarmigan in substantial areas remote from the actual range, rather than the proportion of erroneously classified cells, that makes the CRS model for this species particularly unsatisfactory. Because of this, we restricted our further analyses to Gyrfalcon, Willow Ptarmigan, and Rock Ptarmigan.

The simulated potential distributions of Gyrfalcon, Willow Ptarmigan, and Rock Ptarmigan were broadly similar in location and total extent during the last interglacial period (120 ka BP), the warmest period of the Holocene (7 ka BP) and the $20^{\text {th }}$ Century (Figures 1-4; Table 1). During the LGM, the simulated potential distributions of these species were all markedly different from those at the other three times (Figures 1-4). In all three species, the presence of a large ice sheet over most of northern North America and Greenland greatly reduced the potential range there to a narrow band at $40-45^{\circ} \mathrm{N}$ and to the coast of the Arctic Ocean. In Europe and Asia there was substantial expansion of simulated potential distribution to the south and into areas of western Europe and Beringia that are covered by shallow seas at present. These simulated range expansions, together with the absence of ice sheets over most of northern Asia, allowed the simulated potential distributions of all three species to be much larger in Europe and Asia during the LGM than during the last interglacial, the warmest period of the Holocene and the $20^{\text {th }}$ Century. The smaller potential range extent in North America and the larger range in Europe and Asia approximately cancel each other out, so that the total simulated range extent was quite similar during the LGM 

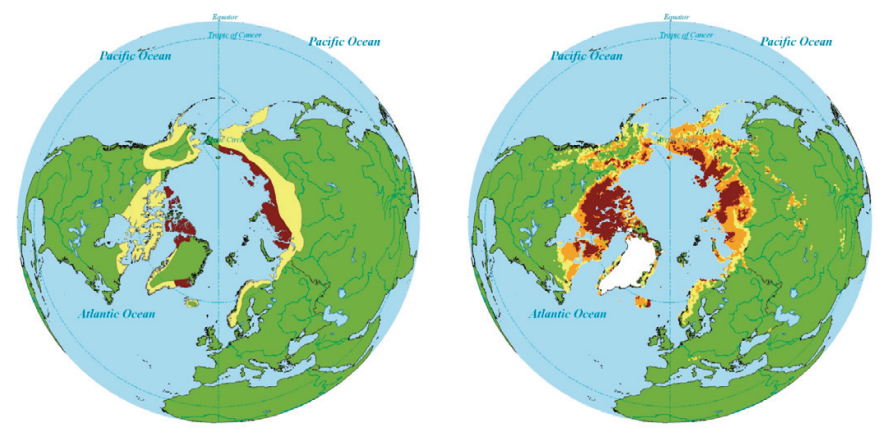

\section{Gyrfalcon}
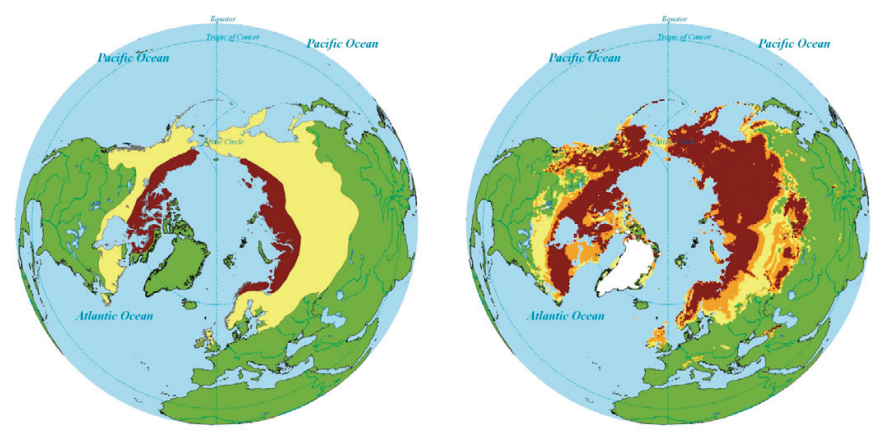

\section{Willow Ptarmigan}
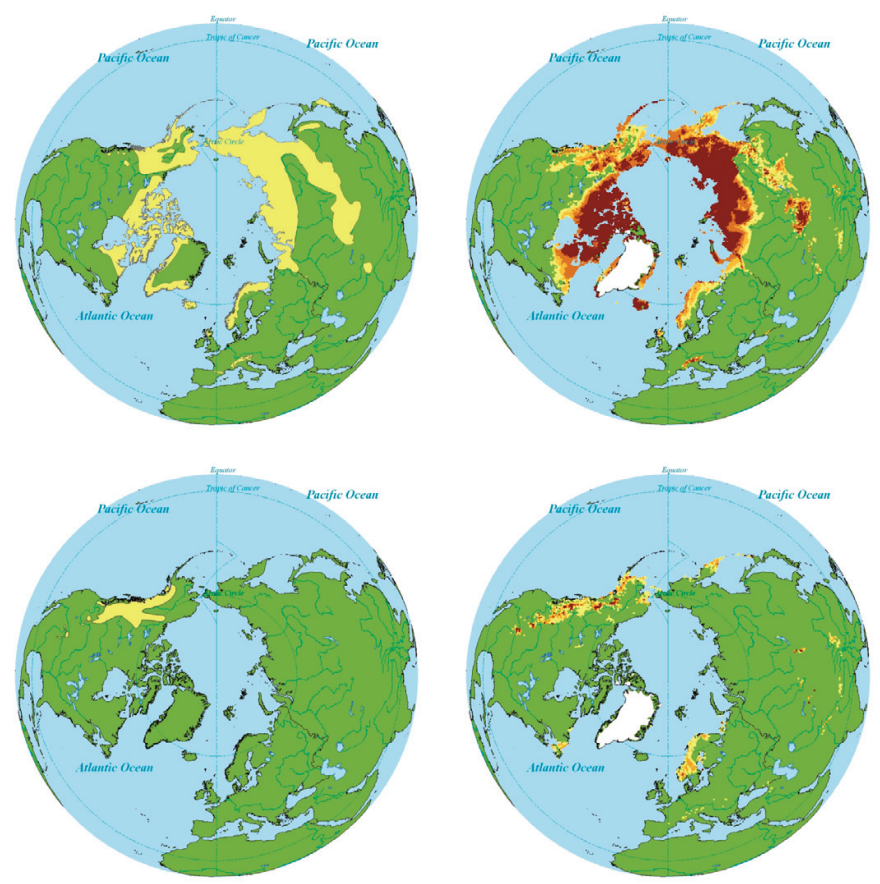

\section{Rock Ptarmigan}

\section{White-tailed Ptarmigan}

Figure 1. Breeding distributions of Gyrfalcon, Willow Ptarmigan, Rock Ptarmigan, and White-tailed Ptarmigan according to BirdLife International (left) in the breeding season only (brown) and all year round (yellow). Also shown is the simulated distribution for 1961-1990 for each species (right) from the CRS models. Yellow, orange, and brown show areas where the species is simulated present at low, medium, and high probability of occurrence. White shows the extent of ice caps. 
Table 1. Extent of the simulated potential range of Gyrfalcon, Willow Ptarmigan, and Rock Ptarmigan as a proportion of the simulated potential range in 1961-1990. Results are shown for CRS models of the species' distributions at three past times and for the late $21^{\text {st }}$ Century with climate projected using three GCMs and the A1B emissions scenario.

\begin{tabular}{lccc}
\hline CRS Model & Gyrfalcon & Willow Ptarmigan & Rock Ptarmigan \\
\hline 120 ka BP last interglacial & 1.133 & 0.990 & 1.115 \\
21 ka BP LGM & 0.974 & 0.754 & 1.067 \\
7 ka BP Holocene & 0.839 & 0.990 & 0.981 \\
2070-2099 GFDL-CM2.1 & 0.599 & 0.671 & 0.673 \\
2070-2099 ECHAM/MPI-OM & 0.356 & 0.596 & 0.472 \\
2070-2099 HadGEM1 & 0.316 & 0.504 & 0.392 \\
\hline
\end{tabular}

to that at the three other times (Table 1). The largest effect of the LGM was a reduction of about one quarter in the simulated range extent of the Willow Ptarmigan (Table 1).

The simulated potential distributions of Gyrfalcon, Willow Ptarmigan, and Rock Ptarmigan were all estimated to contract substantially, compared with the simulated range in 19611990 , under the climatic conditions projected for the late $21^{\text {st }}$ Century using each of the three GCMs. For all three species, the reduction in total simulated potential range extent for the model based upon the ECHAM/MPI-OM GCM was intermediate between the range extent changes for the HadGEM1 model (largest reduction) and the GFDL-CM2.1 model (smallest reduction) (Table 1). Because of this, and to save space, we show mapped distributions in Figures 5-7 only for the extreme models HadGEM1 and GFDL-CM2.1. Simulated potential range extent was reduced, compared with that in the $20^{\text {th }}$ Century, by 40 $68 \%$ for Gyrfalcon, by 33-50\% for Willow Ptarmigan, and by 33-61\% for Rock Ptarmigan (Table 1). Simulated potential range extent in the late $21^{\text {st }}$ Century was also projected to be smaller using all three GCMs, compared with that in the last interglacial, the LGM, and the warmest period of the Holocene.

\section{DISCUSSION}

The simulated potential breeding distributions for the $20^{\text {th }}$ Century from CRS models matched the data used to fit them reasonably well for Gyrfalcon, Willow Ptarmigan, and Rock Ptarmigan, but not White-tailed Ptarmigan, for which the simulated distribution extended to areas of Europe and Asia far beyond the actual distribution in western North America. Differences of this kind between actual distributions and simulations from climate envelope models occur quite frequently when models are applied over large geographical areas within which several phylogenetically and ecologically similar species have evolved in isolation and afterwards spread to fill closely similar ecological niches in different areas. For example, CRS simulations of the breeding distributions of ecologically similar congeneric warblers in southern Europe show erroneous simulated occurrences in the eastern Mediterranean region of species with a western distribution (Sylvia undata, S. conspicillata) and the converse for $S$. rueppelli, which has an eastern distribution (Huntley et al. 2007).

When the CRS models were used to simulate past distributions of Gyrfalcon, Willow Ptarmigan, and Rock Ptarmigan they showed 


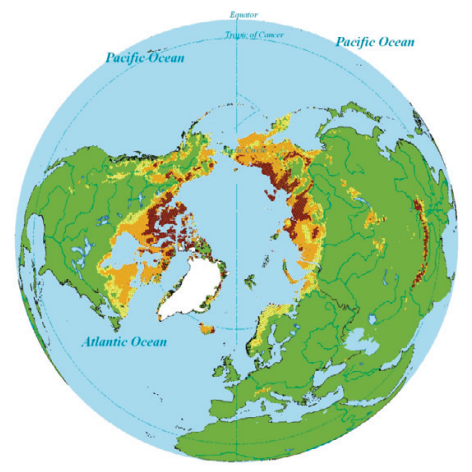

$120 \mathrm{ka}$

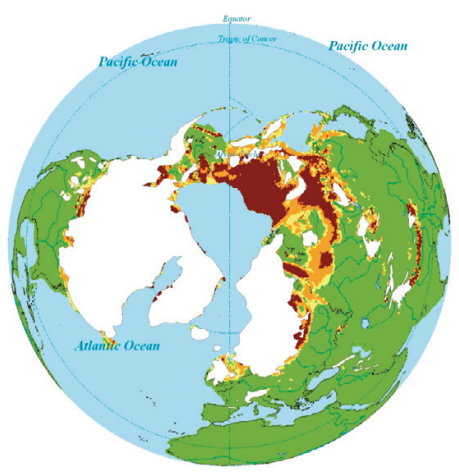

21 ka

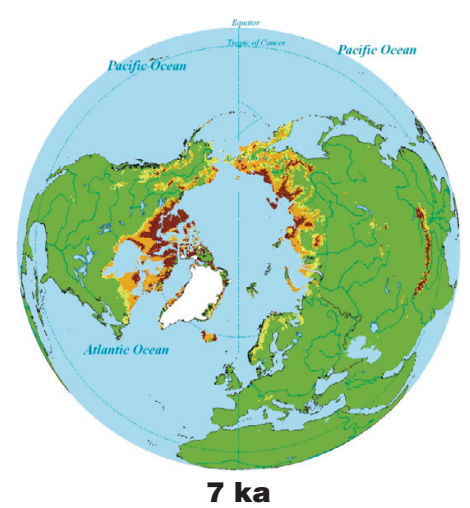

Figure 2. Simulated distribution of Gyrfalcon Falco rusticolus at 120, 21, and 7 ka BP. Green shows the area of land where the species is simulated to be absent $\left(P_{\text {occ }}<0.488\right)$. Yellow, orange, and brown show areas where the species is simulated present at low $\left(0.488<\mathrm{P}_{\text {occ }}<0.6\right)$, medium $\left(0.6<\mathrm{P}_{\text {occ }}<\right.$ $0.8)$, and high $\left(0.8<\mathrm{P}_{\mathrm{occ}}\right)$ probability of occurrence. White shows the extent of ice caps.

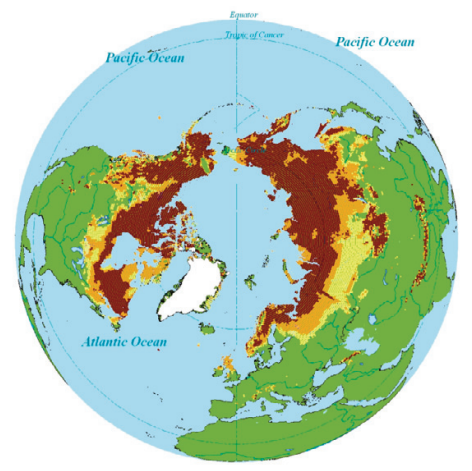

$120 \mathrm{ka}$

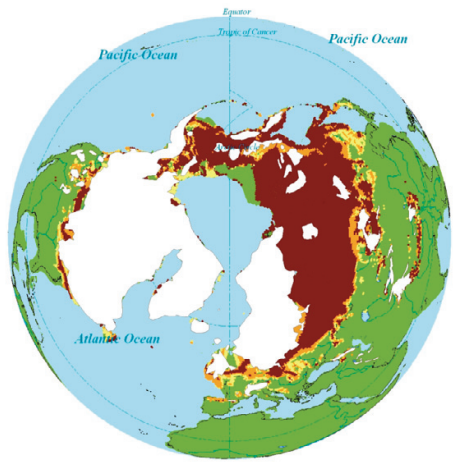

21 ka

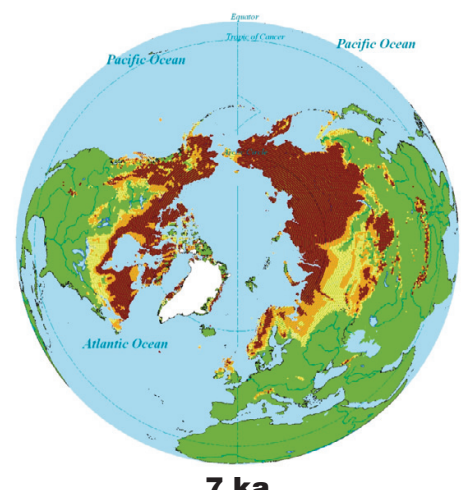

7 ka

Figure 3. Simulated distribution of Willow Ptarmigan Lagopus lagopus at 120, 21, and 7 ka BP. Green shows the area of land where the species is simulated to be absent $\left(\mathrm{P}_{\mathrm{occ}}<0.564\right)$. Yellow, orange, and brown show areas where the species is simulated present at low $\left(0.564<\mathrm{P}_{\text {occ }}<0.6\right)$, medium $(0.6<$ $\left.P_{\text {occ }}<0.8\right)$, and high $(0.8<P$ ) probability of occurrence. White shows the extent of ice caps.

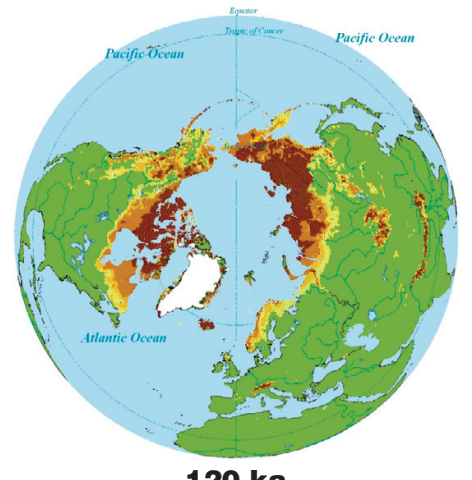

$120 \mathrm{ka}$

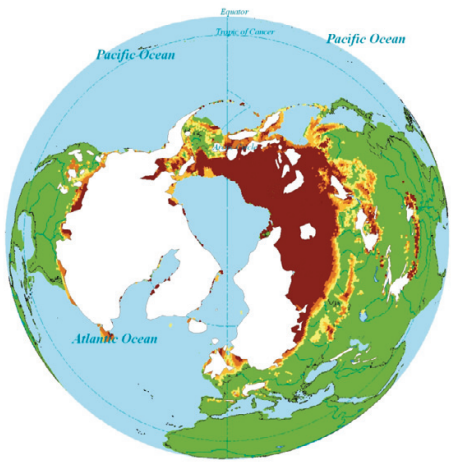

21 ka

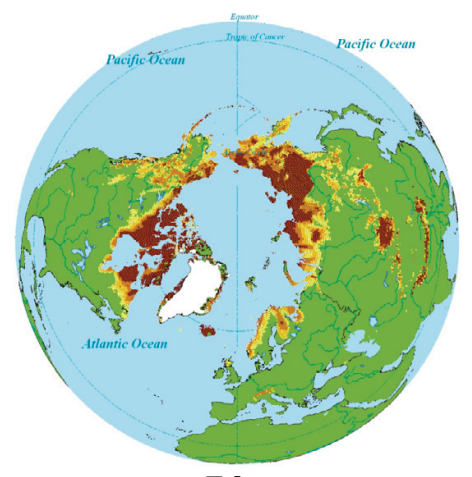

7 ka

Figure 4. Simulated distribution of Rock Ptarmigan Lagopus muta at 120, 21, and 7 ka BP. Green shows the area of land where the species is simulated to be absent $\left(P_{\text {occ }}<0.459\right)$. Yellow, orange, and brown show areas where the species is simulated present at low $\left(0.459<\mathrm{P}_{\text {occ }}<0.6\right)$, medium $(0.6<$ $\left.P_{\text {occ }}<0.8\right)$, and high $\left(0.8<P_{\text {occ }}\right)$ probability of occurrence. White shows the extent of ice caps. 

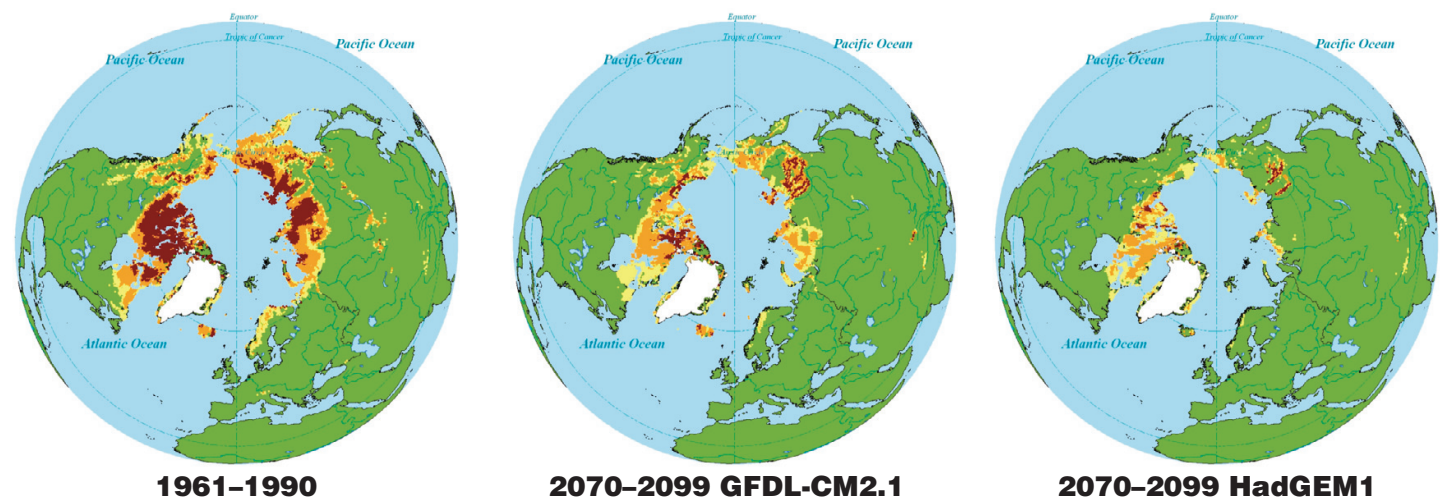

Figure 5. Simulated distribution of Gyrfalcon Falco rusticolus in the period 1961 - 1990 and in 2070 2099 under the A1B emissions scenario and two GCMs: GFDL-CM2.1 and HadGEM1. Green shows the area of land where the species is simulated to be absent $\left(P_{\text {occ }}<0.488\right)$. Yellow, orange, and brown show areas where the species is simulated present at low $\left(0.488<\mathrm{P}_{\text {occ }}<0.6\right)$, medium $\left(0.6<\mathrm{P}_{\text {occ }}<\right.$ $0.8)$, and high $\left(0.8<\mathrm{P}_{\text {occ }}\right)$ probability of occurrence. White shows the extent of ice caps.
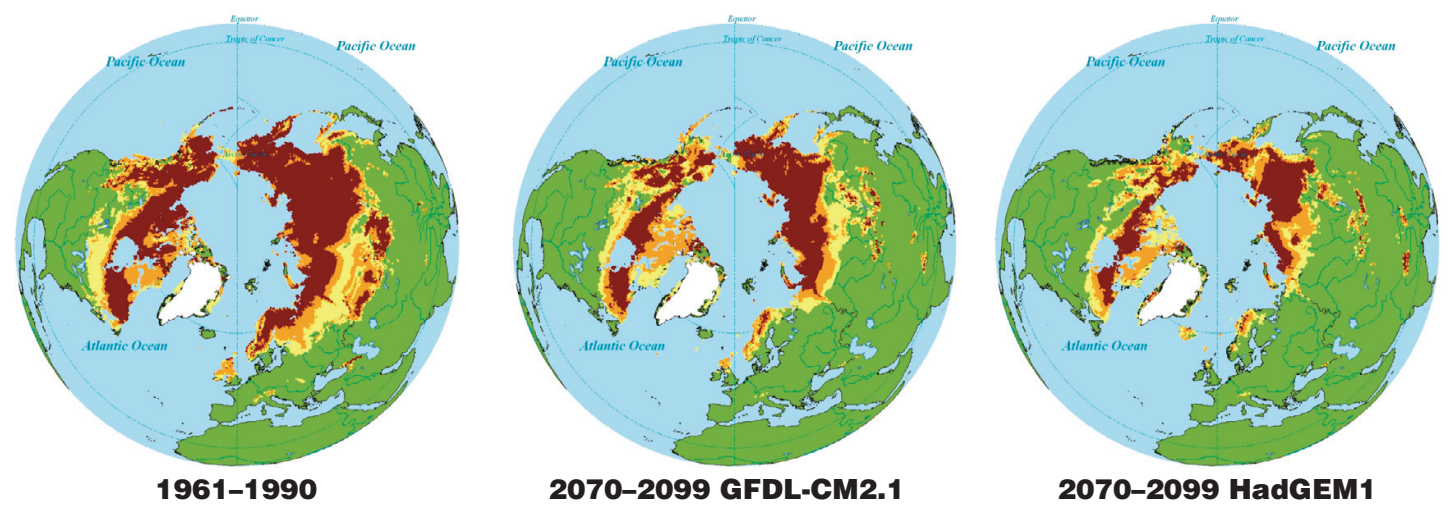

Figure 6. Simulated distribution of Willow Ptarmigan Lagopus lagopus in the period $1961-1990$ and in 2070-2099 under the A1B emissions scenario and two GCMs: GFDL-CM2.1 and HadGEM1. Green shows the area of land where the species is simulated to be absent $\left(\mathrm{P}_{\mathrm{occ}}<0.564\right)$. Yellow, orange, and brown show areas where the species is simulated present at low $\left(0.564<\mathrm{P}_{\mathrm{occ}}<0.6\right)$, medium $(0.6<$ $\left.\mathrm{P}_{\text {occ }}<0.8\right)$, and high $\left(0.8<\mathrm{P}_{\text {occ }}\right)$ probability of occurrence. White shows the extent of ice caps.

remarkably small differences in simulated potential breeding range extent between times with markedly different climates: the last interglacial, the LGM, the warmest period of the Holocene, and the $20^{\text {th }}$ Century. However, the location of the simulated range was markedly different during the LGM than at the other times investigated, with the simulated range extent being much reduced in North America and considerably expanded towards the south in Europe and especially in Asia. During the
LGM, an isolated band of simulated suitable climate for Gyrfalcons and ptarmigan occurred in the mid-latitudes of North America and isolated patches occurred in western Europe. It may be that these areas acted as isolated refugia within which the White-tailed Ptarmigan of western North America and the well-marked subspecies of Willow Ptarmigan Lagopus lagopus scoticus of Britain and Ireland evolved, either during the most recent glaciation or during previous ones when the distribu- 

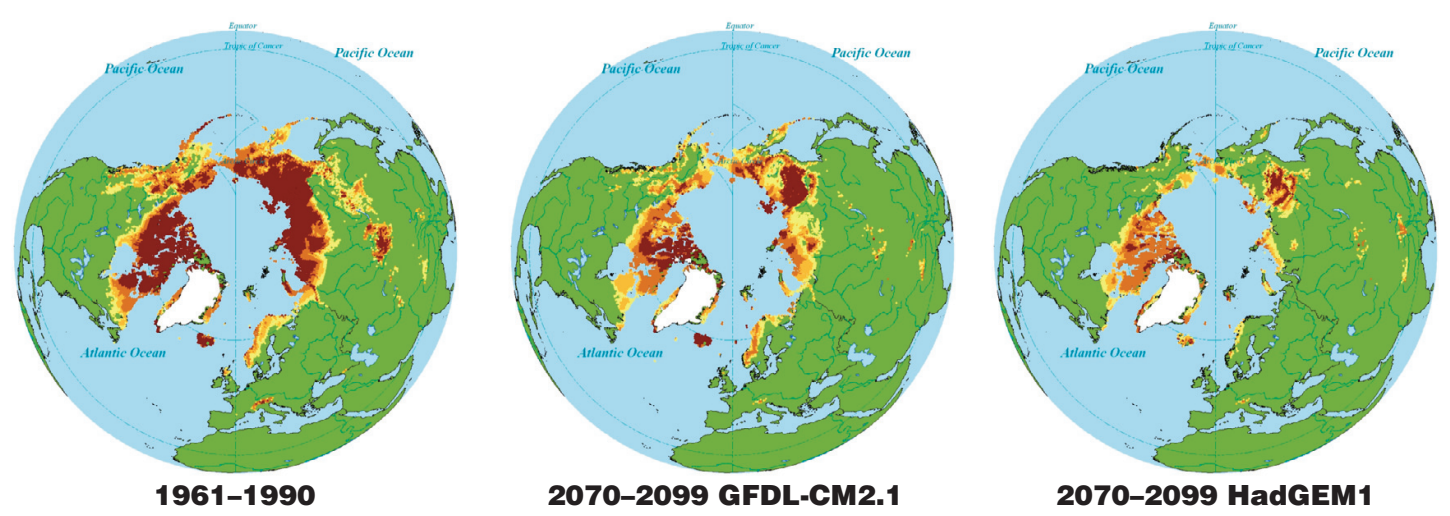

Figure 7. Simulated distribution of Rock Ptarmigan Lagopus muta in the period 1961-1990 and in 2070-2099 under the A1B emissions scenario and two GCMs: GFDL-CM2.1 and HadGEM1. Green shows the area of land where the species is simulated to be absent $\left(\mathrm{P}_{\mathrm{occ}}<0.459\right)$. Yellow, orange, and brown show areas where the species is simulated present at low $\left(0.459<\mathrm{P}_{\text {occ }}<0.6\right)$, medium $(0.6<$ $\left.P_{\text {occ }}<0.8\right)$, and high $\left(0.8<P_{\text {occ }}\right)$ probability of occurrence. White shows the extent of ice caps.

tion of suitable climate during the peak of the glaciations may have been similar.

The projections of Gyrfalcon and ptarmigan distribution in the late $21^{\text {st }}$ Century indicate potential simulated range extents for Gyrfalcon, Willow Ptarmigan, and Rock Ptarmigan substantially smaller than the present breeding range and also smaller than the simulated range extent in the last interglacial, the LGM and the warmest period of the Holocene. All three of the GCMs used to provide the projections of future climatic conditions indicate reductions in potential range extent, although these vary considerably in magnitude. It must be borne in mind that these modeling results represent changes in the distribution that a species would have if it always occupied all areas where the climatic conditions resemble those in which it was recorded in the data used to fit the model. Species may not respond as predicted at all if factors completely unrelated to climate actually limit their range boundaries, or the response may occur with a considerable delay if its mechanism involves ecological processes, such as changes in vegetation or the spread of predators, competitors, or diseases, which take time to play out.

\section{Literature Cited}

Bartlein, P. J., I. C. Prentice, And T. Webb III. 1986. Climatic response surfaces from pollen data for some eastern North American taxa. Journal of Biogeography 13:3557.

Cleveland, W. S., and S. J. Devlin. 1988. Locally weighted regression: An approach to regression analysis by local fitting. Journal of the American Statistical Association 83:596-610.

CoHEN, J. 1960. A coefficient of agreement for nominal scales. Educational and Psychological Measurements 20:37-46.

Cramer, W., ANd I. C. Prentice. 1988. Simulation of soil moisture deficits on a European scale. Norsk Geografisk Tidskrift 42:149-51.

EHLERS, J., AND P. GIBBARD. 2008. Extent and chronology of Quaternary glaciation. Episodes 31:211-218.

Hill, J. K., C. D. Thomas, And B. Huntley. 2003. Modelling present and potential future ranges of European butterflies using climate response surfaces. Pages 149-167 in C. L. Boggs, W. B. Watt, and P. R. Ehrlich (Eds.). Butterflies: Ecology and 
Evolution Taking Flight. University of Chicago Press, Chicago, USA.

HunTley, B. 1995. Plant species' response to climate change: Implications for the conservation of European birds. Ibis 137 (Supplement 1):127-138.

Huntley, B., P. M. Berry, W. P. CRAmer, AND A. P. MCDonALD. 1995. Modelling present and potential future ranges of some European higher plants using climate response surfaces. Journal of Biogeography 22:9671001.

Huntley, B., Y. C. Collingham, R. E. Green, G. M. Hilton, C. RahbeK, and S. G. WILLIS. 2006. Potential impacts of climatic change upon geographical distributions of birds. Ibis 148:8-28.

Huntley, B., R. E Green, Y. C. Collingham, J. K. Hill, S. G. Willis, P. J. Bartlein, W. Cramer, W. J. M. Hagemeijer, and C. J. THOMAS. 2004. The performance of models relating species' geographical distributions to climate is independent of trophic level. Ecology Letters 7:417-26.

Huntley, B., R. E. Green, Y. C. Collingham, AND S. G. WiLlis. 2007. A Climatic Atlas of European Breeding Birds. Lynx Edicions, Barcelona, Spain.

HutChinson, M. F. 1989. A new objective method for spatial interpolation of meteorological variables from irregular networks applied to the estimation of monthly mean solar radiation, temperature, precipitation and windrun. CSIRO, Canberra, Australia. Metz, C. E. 1978. Basic Principles of ROC Analysis. Seminars in Nuclear Medicine 4:283-98.

New, M., M. Hulme, And P. Jones. 1999. Representing twentieth-century space-time climate variability. Part I: Development of a 1961-90 mean monthly terrestrial climatology. Journal of Climate 12:829-56.

Prentice, I. C., W. Cramer, S. P. Harrison, R. Leemans, R. A. Monserud, and A. M. Solomon. 1992. A global biome model based on plant physiology and dominance, soil properties and climate. Journal of Biogeography 19:117-34.

Singarayer, J. S., AND P. J. Valdes. 2010. High-latitude climate sensitivity to icesheet forcing over the last 120 kyr. Quaternary Science Reviews 29:43-55. 